Open Access

Research Article
Res. Agric. Livest. Fish.

Vol. 3, No. 1, April 2016: 145-149

\title{
EFFECT OF INDIGENOUS HERBAL PREPARATIONS ON COCCIDIOSIS OF POULTRY
}

\section{ABM Jalal Uddin ${ }^{1 *}$, Maksudur Rashid ${ }^{1}$, Md. Anwarul Khan ${ }^{2}$, Md. Abdul Awal ${ }^{2}$, Md. $^{2}$ Abdus Sobhan ${ }^{2}$ and AWM Shamsul Islam ${ }^{3}$}

1Department of Livestock Services, Bangladesh; ${ }^{2}$ Department of Pharmacology and ${ }^{3}$ Department of Parasitology, Faculty of Veterinary Science, Bangladesh Agricultural University, Mymensingh-2202, Bangladesh

*Corresponding author: ABM Jalal Uddin; E-mail: abulbasar47@gmail.com

\section{ARTICLE INFOABSTRACT}

\section{Received}

18.03.2016

Accepted

16.04.2016

Online

Key words

Coccidiosis

Phytotherapy

Chicken
30 April 2016

Coccidiosis is a protozoan disease in chickens caused by Eimeria spp with great economic significance. The disease can be controlled by using modern anticoccidial drugs. However large scale and long term use of anticoccidial drugs has led to the resistance. Phytotherapy can be used successfully as an alternative coccidiosis control strategy. Ninety six chicks experimentally infected with coccidiosis were used in the present study. The chicks were divided into 24 groups and were treated with the crude watery extract $(10 \%)$ of mango, pineapple, guava, chutra leaves and thankuni at the dose rate of $1 \mathrm{ml}, 5 \mathrm{ml}$ and $10 \mathrm{ml}$ per $\mathrm{Kg}$ body weight as well as one group was treated with Embazine ${ }^{\circledR}$ at recommended dose. The effects of these drugs were evaluated by oocyst count from faecal sample and the mortality rate. The result shows that the $10 \mathrm{ml} / \mathrm{Kg}$ dose worked better than other dose. In this dose oocyst count significantly decreased $(\mathrm{P}<0.01)$ at the day of 4 (mango), 2 (pineapple), 12 (guava), 2 (chutra) and 4 (thankuni). No oocyst found in feces at the day 8 (chutra and thankuni), 12 (mango and pineapple) whereas on day 12 it shows oocyst in feces in case guava. It shows that mortality encounter $75 \%$ in mango and guava group, $50 \%$ in pineapple and thankuni group, wheras no mortality recorded in chutra group. After completion of experiment it was noted that chutra leaves was most effective at the dose rate of 10 $\mathrm{ml} / \mathrm{kg}$ body weight and effective near about Embazine.

To cite this article: Jalal Uddin ABM, Rashid M,Khan Al, Awal MA, Sobhan MA and Islam AWMS, 2016. Effect of indigenous herbal preparations on coccidiosis of poultry. Res. Agric. Livest. Fish. 3 (1): 145-149.

This is an open access article licensed under the terms of the Creative Commons Attribution 4.0 International License

www.agroaid-bd.org/ralf, E-mail: editor.ralf@gmail.com 


\section{INTRODUCTION}

Coccidiosis is a common infectious disease in poultry, causing major economic losses. The protozoan parasite of the genus Eimeriaspp in the cecum and intestinal tract of poultry and produces tissue damage, resulting in reduced growth and increased susceptibility to pathogens (McDougald, 2003) such as Clostridium perfringens, leading to necrotic enteritis (Helmboldt and Bryant, 1971; Maxy and Page, 1977; Shane et al., 1985). Coccidiosis is considered as one of the serious problems for poultry development in our country. Srinivasan (1959) reported $90-100 \%$ mortality in chicken to be associated with coccidiosis in India. Because of favourable climatic condition this disease is prevalent seriously in Bangladesh also. Mortality in young birds which varies from $25-90 \%$ days of infection is predominant factor of economic loss (samad 1988). If we can establish the traditional system of medicine it will be highly benificial for the farmers and for the overall improvement of the livestock.

The world health organization (WHO) has recognized the necessity for investing and mobilizing the ancient medicinal practice for meeting the primary health needs of the people, the traditioal systems will provide basic health services to the rural population of the developing country like ours. No systemic assessment of the impact of traditional system on livestock health has yet been attempted, nor does it have an organized apporach at present. Due to vast usage of sulphanilamide, amprolium or synthetic chemical compounds for the treatment of coccidiosis in poultry results in emergence of drug resistant anticocccidial herbs preparations are required. Several herbs possess anti coccidial effects such as urticadicia, mangoferousindica, hydrocotylasiatica etc.So this study of the indigenous system of herbal preparation (mango, pineapples, guava, chutra and thankuni) has been undertaken to determine the anticoccidial effects in chickens.

\section{MATERIALS AND METHODS}

The experiment was performed in the Department of Pharmacology, Bangladesh Agricultural University, Mymensingh, Bangladesh.Ninety six chicks of white leg horn breed infected with coccidiosis and weighing between 250-350 gms were used for this study during March to June 1989. All the chicks were 4 weeks of age. At first ten chicks suffering from coccidiosis were collected from the private farm. From these diseased chicks, coccidiosis was produced in rest of the chicks. All the infected coccidiosis chicks were kept in good housing condition free from any contamination and they were maintained on a balance ration consisting of $3200 \mathrm{k} \mathrm{cal} / \mathrm{kg}$ feed and $20 \%$ protein and water ad lib.

The procedure employed in the present study consisted of 3 steps. Viz: A. Collection and preparation of crude watery extract $(10 \%)$ of medicinal plants; B. Studies on the efficacy of different crude watery extracts of medicinal plants against coccidiosis in chicks; C. Studies on the comparative efficacy of crude watery extract of selected medicinal plants with that of modern patent drug Embazine against cocccidiosis in chicks.

\section{A. Collection and preparation of crude watery extract $(10 \%)$ of medicinal plants.}

The leaves of selected plants such as mango, pineapple, guava, chutra and the whole of thankuni were seleted in fresh condition. The collected growing mango, pineapple, guava, chutra and the whole of thankuni were washed thoroughly with water. Then these were cut into small pieces and dried in the sun for 7 days. These dried sample were taken into equal parts by measuring with balance and pulverized with the help of a grinding machine. Finally the ground power was preserved in an air tight bottle. $200 \mathrm{gms}$ powders of fresh leaves of each plants was prepared.From the ground powder of the sample $10 \mathrm{gms}$ from each sample was taken in $100 \mathrm{ml}$ of distilled water in a clean beaker and mixed thoroughly by a stirrer. Then the beaker was placed on a heater and the content of the beaker was boiled for 15-20 minutes. After replace from the heater the contents were filtered by passing through fine muslin. The watery extracts was then placed in a sterilized air tight bottle and labeled for further study.

For administration to the chick, fresh crude watery extracts were prepared daily. Each kind of samples was kept in separate glass bottle with labeling. 


\section{B. Studies on the efficacy of different crude watery extracts of medicinal plants against coccidiosis in chicks.}

Eighty infected (coccidiosis) chicks were used for this study. The disease condition of coccidiosis of the chicks were confirmed by observing visiable signs and symptoms and also by examining the presence of oocyst in the faeces. All the infected chicks were randomly divided into 20 groups each consisting of 4 chicks. All the chicks were housed group by group in 20 different cages. The cages were numbered as I to XX. Group I chicks did not receive any treatment and was kept as control. Group II, III, and IV chicks were treated with crude watery extract of mango leaves at the dose rate of $1 \mathrm{ml}, 5 \mathrm{ml}$ and $10 \mathrm{ml}$ per $\mathrm{kg}$ body weight respectively.

Groups VI,VII and VIII chicks received crude watery extracts of pine apple leaves at the dose rate of $1 \mathrm{ml}, 5 \mathrm{ml}$ and $10 \mathrm{ml}$ per $\mathrm{kg}$ body weight respectively. Group $\mathrm{V}$ chicks were kept as control without giving any treatment.Similarly group IX chicks did not receive any treatment and was kept as control. Group X, XI, XII, chicks received crude watery extracts of guava leaves at the dose rate of $1 \mathrm{ml}, 5 \mathrm{ml}$ and $10 \mathrm{ml}$ per $\mathrm{kg}$ body weight respectively.Likewise groups XIV, XV and XVI chicks were given crude watery extract of chutra leaves at the dose rate of $1 \mathrm{ml}, 5 \mathrm{ml}$ and $10 \mathrm{ml}$ per kg body weight respectively. Here chicks of group XIII was kept as control without providing any treatment. In the last group the chicks of group XVII was kept as control which received no treatment. Crude watery extracts of thankuni leaves at the dose rate of $1 \mathrm{ml}, 5 \mathrm{ml}$ and $10 \mathrm{ml}$ per $\mathrm{kg}$ body weight were administered to groups XVIII, XIX and XX chicks, respectively.

Crude watery extracts of five medicinal plants were administered orally by the help of a dropper. The treatment was repeated twice daily (morning and evening) for 12 days at the same dose and route. After treatment with crude watery extracts of five different medicinal plants all the treated chicks were observed carefully for 12 days and following parameters were studied.

Clinical examination:The time of disappearance of clinical signs and symptoms of coccidiosis and mortality if any was recorded carefully in the chicks treated with different medicinal watery extract.

Faecalsample examination:Faecal samples were obtained from all the treated 4 chicks of each group on every alternate day. At 9.00 a.m. in order to study the presence/absence of oocysts after treatment of chicks with watery extract of medicinal plants. Fecal sample was taken $1 \mathrm{gm}$ from each group of chicks.

\section{Comparative efficacy of chutra and thankuni leaves with that of Embazine}

Sixteen infected (coccidiosis) chicks were used for this study. All the chicks were randomly divided into 4 groups each consisting of 4 chicks. The chicks and were kept in 4 different cages group wise and numbered as I to IV. Group I chicks was kept as control without giving any treatment. Group II and III chicks were given crude watery extract of chutra and thankuni leaves respectively at the dose rate of $10 \mathrm{ml} / \mathrm{kg}$ body weight. The dose $(10 \mathrm{ml} / \mathrm{kg})$ of crude watery extract was found to be most effective in treating the chicks infected with coccidiosis. On the other hand, group IV chicks received Embazine at the dose rate of $15 \mathrm{ml} /$ gallon of drinking water and was supplied continuously for 3 days and fresh water was given for two days following Embazine again for 3 consecutive days.After administration of crude watery extracts and Embazine to different groups of chicks as mentioned above,all the treated chicks were kept under close observation for a period of 12 days.

\section{RESULTS AND DISCUSSION}

Ninety six chicks experimentally infected with coccidiosis were used in the present study with the objectives of 1) determining the effects of crude watery extract of mango, pineapple, guava, chutra leaves and whole of the thankuni and 2) the evaluating the comparative efficacy of crude watery extract of chutra leaves and whole of the thankuni with that of patent modern drug Embazine against coccidiosis in chicks.

The crude watery extract of mango leaves in doses of $1 \mathrm{ml}, 5 \mathrm{ml}$ and $10 \mathrm{ml} / \mathrm{kg}$ body weight significantly decreased the oocyst count in groups II to IV chicks respectively. The maximum reduction to the extent of 64 -and 36 percent was observed following 1 and $5 \mathrm{ml} / \mathrm{kg}$ body weight respectively. The reduction of oocyst was maximum on day 12 day following $10 \mathrm{ml} / \mathrm{kg}$ body weight. In group 11, three chicks died within 4-6 days of treatment. The rest chick of this group collapsed within 8 days of medication. In group III, all the chicks died within 2-6 days of treatment. Ultimately none of the chicks of these two groups 
survived following 1 and $5 \mathrm{ml} / \mathrm{kg}$ body weight crude watery extract of mango leaves. In group IV, three chicks died within 10 days of medication and only one chick of this group(receiving $10 \mathrm{ml} / \mathrm{kg}$ extract) survived.

Following 1,5 and $10 \mathrm{ml} / \mathrm{kg}$ body weight crude watery extracts of pine apple leaves, oocyst count reduced significantly to the extent of 45,57 and 88 percent in groups VI, VII and VIII chicks respectively. In group VI chicks 3 chicks died within 2-4 days after treatment with $1 \mathrm{ml} / \mathrm{kg}$ body weight of crude watery extract of pine apple leaves. One chick of this group survived throughout the study period. After administration of $5 \mathrm{ml} / \mathrm{kg}$ body weight of pine apple extracts all the chicks died with 8 days of treatment. Whereas 2 chick died (within 2-8day) and 2 chick survived following $10 \mathrm{ml} / \mathrm{kg}$ body weight of pine apple extract.

Significant decrease of oocyst count to the extent of 9-44 percent was observed following administration of higher doses i.e. $5 \mathrm{ml}, 10 \mathrm{ml} / \mathrm{kg}$ body weight of crude watery extracts of guava leaves against coccidiosis in groups XI and XII chicks whereas oocyst count was not decreased significantly after administration of $1 \mathrm{ml} / \mathrm{kg}$ of guava extract in group $X$ and $X I$ chicks.

All the chicks of groups $X$ and $X I$ receiving $1 \mathrm{ml}$ and $5 \mathrm{ml} / \mathrm{kg}$ body weight crude watery extracts of guava leaves died within 8 days of medication. In group XII three chicks died within 10 days and only one chick survived in this group.

In group XVI chicks, no oocyst was found on day 8 and all the chicks survived following administration of $10 \mathrm{ml} / \mathrm{kg}$ body weight of crude watery extract of chutra leaves. Oocysts disappeared in group XIV and XV chicks within 8-10 days after treatment with $1 \mathrm{ml}$ and $5 \mathrm{ml} / \mathrm{kg}$ body weight of chutra leaves extract. One chick in each group of XIV and XV died within 4-6 days following administration of 1 and $5 \mathrm{ml} / \mathrm{kg}$ body weight chutra leaves extract. Other 3 chicks of these groups survived during the study period.

No oocysts were observed after 8 days in groups XVIII, XIV and XX chicks following administration of 1,5 and $10 \mathrm{ml} / \mathrm{kg}$ body weight of crude watery extracts of whole of thankuni. However one chick in each group of XIX and XX died within 4-6 days after administration of 5 and $10 \mathrm{ml} / \mathrm{kg}$ body weight of thankuni extracts. Two of 4 chicks died within 4-6 days after administration of $1 \mathrm{ml} / \mathrm{kg}$ body weight of thankuni extracts in group XVIII chicks.

Sixteen chicks were used for comparative study. They were divided into 4 groups each comprising of 4 chicks. Group I chicks was kept as control giving no treatment. The administration of crude watery extracts of whole of thankuni to group II chicks could not save all of the chicks. One chick of this group died within 4 days of medication, other 3 chicks of this group survived and become normal. The oocyst count also decreased significantly and found to be absent in faecal sample of surviving chicks on 12 day of treatment.

In group III chicks no oocyst was observed after 6 days of treatment with crude watery extract of chutra leaves and all the chicks of this group remained alive during the study period. Similarly, administration of Embazine in dose rate of $15 \mathrm{ml} / \mathrm{gallon}$ water to group IV chicks afforded complete protection against coccidiosis and oocyst was disappeared in the faecal sample after 4 days of treatment.

Clinical symptoms of coccidiosis i.e. blood mixed faeces in droppings, inappetance, ruffled feather, drowsiness etc. started to disappear from 3-4 days onwards in all the surviving chicks following administration of crude watery extract of different medicinal plants.

Post mortem examination was performed in the dead chick of all groups. Accumulations of blood in ceca and cecalcores, free blood in lumen of intestine were observed. The ceca become dark red in colour and firmer than normal. Necrotic mass of yellowish, cheesy blood stained debris were also observed. From the above findings it may be noted that some herbal extracts have anticoccidial activities. Almost similar types of findings were reported by many investigators (Mathis et al. 1984; Kirtikar and Basu, 1980; Siddique, 1961). Extracts of chutra leaves was more effective than other extracts (mango, guava, pineapple, thankuni).Due to unavailability of literature, the findings not properly explained in this study. In near furure the investigation needs to be performed to demonstrate the active ingredients of chutra having anticoccidial activity. 


\section{REFERENCES}

1. Arsad MA, Khan $\mathrm{AH}$ and Zaman MB, 1956. Anote on the plants of medicinal values found in Pakistan. Medicinal Plant Branch, Pak. Forest Research Institute Abottabad.

2. Dhama K, Latheef KS, Mani S, Samad HA, Karthik K, Tiwari R, Khan RU, Alagawany M, Farag MR, Alam, GM, Laudadio V and Tufarelli V, 2015. Multiple Beneficial Applications and Modes of Action of Herbs in Poultry Health and Production-A Review. International Journal of Pharmacology, 11: 152176.

3. FAO, 1980. Preliminary Study on Traditioal Systems of Veterinary Medicine. FAO regular programme, No. RAPA43. p 49-58.

4. Fernando ST, 1957. Coccidia of Goats in Ceylon - Preliminary Observations. Ceylon Veterinary Journal 1-2: 19-23.

5. Fish FF, 1932. Some factors in the control of coccidiosis of poultry. Journal of American Veterinary Medicine, Ass. 80: 543-559.

6. Gill BS, 1954. Speciation and Viability of Poultry Coccidia in 120 fecal samples preserved in $2.5 \% \mathrm{~K}$ dichromate Solution. Indian Journal of Veterinary Science, 24: 245-247.

7. Harlen HDA and James AA, 1978. First lesson in duck raising. IVS Bulletin No-2, Dhaka, Bangladesh, pp. 17-18.

8. Kirtikar and Base, 1980. Indian Medicinal plants. Publisher: Bishen Singh Mahendra Pal Singh, Vol. 1 Edn-2, pp. 652-653.

9. Mathis GF McDougald LR, Mc Murray B, 1984. Effectiveness of therapeutic Anticoccidial drugs against recently isolated coccidia. Poultry Science, 63: 1149-53.

10. McDougald LR, 2003. Coccidiosis. In: Disease of Poultry (eds) Y. M. Saif, H. J. Barnes, J. R. Glisson, A. M. Fadly, L.R. McDougald, and D. E. Swayne. lowa State Press, Ames, lowa, USA. pp. 974-991.

11. Siddique S, 1961. International Symposium of Medicinal Plants of the Middle East. Pakistan Journal of Science, 13: 6-11.

12. Soltys A, 1970. Effects of some of external environmental factors on the infectivity of Eimeriatenellaoocystswiad. Parazyt,16: 175-181. 